\title{
Factors Causing Stress: A Study of Indian Call Centres
}

\author{
Dr. Mohsin Aziz \\ Lecturer, Department of Business Studies, Higher College of Technology \\ Ministry of Manpower, Muscat, Sultanate of Oman \\ Email: mohsinzilli@rediffmail.com
}

\section{Doi:10.5901/ajis.2013.v2n8p247}

\begin{abstract}
Business Process Outsourcing (BPO) is the process of contracting out services to a third party vender either domestically or offshore. The purpose is to rationalise cost by getting rid of non core components of business. Over the last one decade, the BPO organisations in India have witnessed high growth as fierce competition among Multinational organisations to reduce cost has prompted them to shift their non core operations to low cost and high quality destinations like India. Call centres fall under the general umbrella of business process outsourcing.Stress is an unavoidable part of an individual's working life. Various studies conducted on Indian call centre organisations have highlighted the prevalence of high occupational stress. Call centre employees work long shifts, often during night, thus, becoming easy victims of various psycho-physiological ailments. For present study, convenience sampling was used to collect information from three different organisations in National Capital Region in India. Personal interviews were conducted to identify the various factors causing occupational stress among employees of call centre organisations. The major factors identified are monitoring of employees, angry customers, changing identity, performance metrics, and night shift.
\end{abstract}

Keywords: Business Process Outsourcing, Call Centre, Stress Factors, India

\section{Introduction}

The last decade and a half has seen a massive growth in the number of Business Process Outsourcing Organisations in India. Business Process Outsourcing is the process of contracting out services to a third party vendor domestically or offshore. Intense competition among multinationals to reduce cost has prompted many organisations to shift their non core operations to low cost and high quality destinations like India (Faruquie et. al. 2005)

The Indian outsourcing industry emerged in mid 1990's. However, the sector got a major boost at the end of 1990's when Multi National Companies started establishing wholly owned subsidiaries which catered to the off shoring requirement of their parent companies. American Express, GE Capital and British Airways were some of the pioneers in the Indian outsourcing market. Today the Indian business process outsourcing industry has matured and is off shoring servicing ranging from customer care, medical transcription, medical billing services, database management, web sales / marketing, accounting, tax processing, document management, telesales, telemarketing, human resource hiring \& biotech research (Outsource2india, 2011).

\section{Stress and Call Centers}

Modern age has been called the 'Age of Anxiety and Stress' (Coleman, 1976). Stress is a dynamic condition in which an individual is confronted with an opportunity, constraint, or demand related to what he or she desires and for which the outcome is perceived to be both uncertain and important (Selye, 1936; Selye, 1956)

Work stress has emerged as a global problem (Cooper \& Cartwright, 1994) and intense or prolonged stress can have negative impact on an individual's mental and physical health (Cooper et. al. 2001). It may result in problems such as hyper-irritability, sleep disturbances, disturbed interpersonal relationships, as well as various somatic and psychological patterns detrimental to the individual (Hafner, 1968; Strange \& Brown, 1970; Hersen, 1972; Wolfe, 1986). Workplace stress has been found to be responsible for poor quality of work, low productivity, decreased performance, increased absenteeism and turnover. Consequently it increases cost for the organization (Cooper \& Cartwright, 1994; Edworthy, 2000; MacDonald, 2003). Various studies have identified call centre as a stressful place to work (Fernie \& Metcalf, 1998; Knights \& McCabe, 1998; Mulholland, 2002; Patel, 2008; Aziz, 2012). 


\section{Nature of Calls handled}

All the subjects were handling only inbound calls. The call centers chosen for this study were servicing only American and British customers.

\section{Methodology}

For the present study, three different business process outsourcing organisations from National Capital Region (NCR) were selected. 50 call handlers were chosen from the three organisations. Convenience sampling was used for both choosing the organisations as well as the call handlers. Interviews were conducted with all the 50 call handlers. Based on the response, in-depth interviews were conducted with 3 female and 5 male call handlers to get further insight into the matter. The interviews were conducted over a period of around two months i.e. July and August 2012.

Table 1: Distribution of respondents by sector serviced

\begin{tabular}{|l|c|}
\hline \multicolumn{1}{|c|}{ Sector } & Number \\
\hline Retail & 14 \\
\hline Telecommunication & 11 \\
\hline Transport and Travel & 8 \\
\hline Utilities & 7 \\
\hline Hotel and Leisure & 7 \\
\hline Others & 3 \\
\hline
\end{tabular}

Table 2: Age distribution of respondents

\begin{tabular}{|c|c|}
\hline Age Bracket & No. \\
\hline $20-23$ & 23 \\
\hline $24-26$ & 14 \\
\hline $27-30$ & 9 \\
\hline 30 and above & 4 \\
\hline
\end{tabular}

Table 3: Gender Composition of the sample

\begin{tabular}{|c|c|}
\hline Gender & Number \\
\hline Male & $33(66 \%)$ \\
\hline Female & $17(34 \%)$ \\
\hline
\end{tabular}

\section{Factors Causing Stress}

The study found many causes as reported by the employees interviewed. However, the present study will focus on only the top five factors causing stress among the business process outsourcing employees.

- Monitoring

- Angry Customer

- Changing identity

- Performance Metrics

- $\quad$ Night Shift

\section{Monitoring}

As technology has improved, it has made possible for organisations to monitor their employees more as compared to the past. However, the amount of monitoring which takes place in call centers is much higher as compared to other organisations. Computers which are meant to reduce workload are used as merciless monitoring tools by call centers (Peaucelle, 2000). According to Taylor and Bain (1999) "If anything distinguishes a call centre worker it is both the extent 
to which they are subject to monitoring and the unrelenting pressure to conform to acceptable forms of speech, whether scripted or not".

In the present study also, monitoring emerged as the most common factor causing stress as reported by BPO employees. High level of surveillance is prevalent in call centers. Team leaders often observe calls for assessing the service quality provided by call handlers. This is done either by listening to live calls or recording calls and analyzing them later for feedback. Team leaders listen to live calls, mostly without the knowledge of the call handler, to provide feedback on performance. This helps in identifying additional training needs for individual employees as well as helps in identifying customer needs, so that better service may be provided to customers in future. Calls are also recorded and analysed by team leaders against set criteria which may include:

- Time taken per call

- Ability to stick to the script

- Ability to handle angry customers

- Pronunciation and accent

- Voice Modulation

Majority of the employees perceived monitoring as unnerving. High level of monitoring also results in the inability of call handlers to take adequate breaks which results in high level of physical as well as mental fatigue. As one of the employee said "I am in this job for more than a year now. Still, the feeling that somebody is actually watching or hearing me, that too without my knowledge, is quite unnerving. You can not be yourself. You have to be always on guard. Maybe you have done a good job for the whole night. Still it is possible that you get a rude customer and you are unable to maintain your cool and that is the same time your team leader decides to monitor your call. That means a negative against your name for that one mistake. Come on, give me a break".

\section{Performance Metrics}

Performance metrics has emerged as a major cause of concern for employees. Performance in a call centre is related to the monitoring of calls. There are different measures of performance which are part of performance metrics. Some of the most frequently used measures of performance are:

- $\quad$ Average Call Handle Time (ACHT)

- Service Level (SL)

- Abandon Rate or Call Abandon Rate (ABN or CAR)

- Agent Utilisation Rate (AUR)

- First Call Resolution (FCR)

- Adherence to schedule

The nature of these performance metrics is such that it makes it impossible for the employee to take long breaks. The rigid schedule does not allow for much downtime (Poster, 2007). For example adherence to schedule is a measurement of how much time during shift a call handler is logged in and handling contacts or is available to handle calls. The average adherence to schedule for organisations where the study was done is 90 percent. It means that the call handler is expected to be available to handle contacts $90 / 100^{*} 60$ minutes. This means that the call handler should be available for 54 minutes for each hour of work time. Assuming working hours to be 8 in a day, the call handler should be available for 7 hours and 12 minutes to handle calls. This puts a lot of work pressure on the call handlers.

Peaucelle (2000) has rightly pointed out that the "Conditions prevailing in this situation resemble those of Taylorian workshops, where work rates are close to the maximum that workers can manage. There are very few breaks in between different tasks and the deadlines create a high level of tension. Operators consequently respond to these hard working conditions with high turnover rates and social movements".

\section{Angry Customers}

A major chunk of business for Indian call centre industry comes from the West, particularly United States and United Kingdom. Historically, companies outsourced their back office operations to India because to two obvious advantages. One was low salaries in India as compared to the West and second was language. India had a large English speaking population. English is no longer a major advantage for India. English spoken by India call handlers is heavily accented. This often results in customer getting angry and abusive towards the call handlers. Despite call centre's putting a lot of money in training young Indians in neutral accents, the Indian accents still comes through. The sound of an Indian accent 
often makes customers angry. According to Cathy Tornbohm, Vice President, BPO research, Gartner, "India as a delivery location is still challenged by English being spoken with strong accents, which can sometimes be hard to understand" (Arun, 2013). Some British and American companies have even shifted out their operations out of India due to customer dissatisfaction with Indian accents (Vaidyanathan, 2011). There are political as well as social reasons for it. Customers in United States as well as in United Kingdom have become quite sensitive to political issue of jobs moving out to India (Gentleman, 2005). At times the abuses hurled at call handlers are purely racist in nature. According to McPhate (2005) Indian call center workers are facing "abuse from Americans, whose tantrums are sometimes racist and often inspired by anger over outsourcing". What accentuates the problem is the fact that most of the call handlers are quite young and are unable to take this type of abuse. They find it difficult to cope with the abuse and the performance metric is affected. This only exacerbates the situation. The situation has prompted many companies, particularly American, to shift their operations to Philippines. One reason for growing preference for Philippines is preference for American accent. Although Filipino call centre executives cost more than their Indian counterparts but they speak in an accent which is more understandable to the American customers due to historical contacts between the two countries (Bajaj, 2011).

\section{Changing Identity}

A surprising finding is that many employees found changing their identity as something disturbing. During interviews many call handlers told that fancy names and learning to speak in American or British accent was fun in the beginning. However, after sometime, many of them lost the initial enthusiasm. On the contrary, some even found it disturbing. Call handlers who had faced abuse over call after being found to be Indian by the customers were particularly more concerned. They argued that why should they change their identity. They should be accepted as they are. Although none of the call handlers admitted for themselves but three cited examples of their coworkers taking psychiatric help for depression, bipolar disorder and dissociative identity disorder (also called multiple identity disorder). The reason for the above problems can range from changing identity to monotonous work with little scope for learning and development. Earlier study by Sudhashree et. al. (2005) also reported loss of identity among call handlers.

On the other hand, many took it as a part and parcel of the job and had no qualms in changing their identity. However, changing identity may also result in a call centre worker identifying so strongly with what they perceive to be American way of life that they start believing their call personas to be an authentic identity (Pal \& Buzzanell, 2008). This type of behavior was evident in the present research also as some of the respondents said that they prefer being called by their western names as it sounds more 'hip' (the word used by one of the respondent)

\section{Night Shift}

The call centers in the present study were servicing exclusively American and British clients. The time difference particularly between India and United States automatically entails night shift for the employees. This brings new opportunities as well as new problems. According to Slater (2004) "For many young people, especially women, callcenter work means money, independence and an informal environment where they can wear and say what they like. Along with training in American accents and geography, India's legions of call-center employees are absorbing new ideas about family, material possessions and romance". Working at call centres gives opportunity to the young Indians to be upwardly mobile in the society. At the same time, working at night brings up issues, particularly for women employees which are not prevalent in a day time work. Call Centre work carries sexual stigma due to late night work and may result in being distanced by family and community (Pradhan \& Abraham, 2005). Although not confined to night, some other problems that put constraints on women working at night are carjacking, abduction, assault and even rape (News24, 2008; Kumar, 2013). Many women employees in this study have pointed to these factors as hampering their jobs. They reported to be under pressure from families to change jobs. It is interesting to note the all the female employees interviewed were looking for a day time job.

Earlier studies have identified differences in the level of stress faced by males and females (Aziz, 2003; Aziz, 2007). In the present study also, males have not reported social pressure while working at night but they also face certain problems which are common with female employees. Many of them reported that despite working for more than a year or two, still they were unable to adjust to day time sleeping and as a result are facing health issues. Their traditional social circles have also been affected by their night shifts. They find it impossible to move around with the family in the day time or attend late night social gatherings with the family or with the friends. All this has resulted in social isolation and as a consequence increased stress. 


\section{Conclusion}

The present study has highlighted the various factors that cause stress for call centre employees. As the industry matures, certain human resource policies have evolved to overcome these issues. Many organisations have increased rest periods and have started providing training to their employees to manage rude and abusive customers. Some have even allowed their employees to hang up on abusive customers. Till recently, this was a sack-able offence.

Today stress has moved from the realm of personal problem to corporate balance sheet. As the turnover rate increases, the organisations in the industry have increasingly realized that they have to come up with practical solutions to overcome these issues, otherwise, they will not only keep losing employees but also business.

\section{References}

Arun, M. G. (2013) Last call: India's about to hang up on call centre culture, India Today, March 15, Available at: http://indiatoday.intoday.in/story/bpo-industry-call-centre-culture-dying-in-india/1/258032.html. Accessed on 21. 06. 2013.

Aziz, M. (2003) Organizational role stress among Indian information technology Professionals, Asia-Pacific Newsletter on Occupational Health and Safety, Vol. 10, pp. 31-33

Aziz, M. (2007) Organizational role stress: an investigation of gender differences, Studia Psychologica, Vol. 49, No. 11, pp. 53-61

Aziz, M. (2012) Occupational role stress: a study of Indian business process outsourcing employees, Mediterranean Journal of Social Sciences, Vol. 3, No. 9, pp. 103-109

Bajaj, V. (2011) A new capital of call centers, Available at: http://www.nytimes.com/2011/11/26/business/philippines-overtakes-india-ashub-of-call-centers.html?pagewanted=all\&_r=0. Accessed on 22.06.2013.

Coleman, J. C. (1976) Abnormal psychology and modern life (Indian reprint), Taraporewalla: Bombay

Cooper, C. L. \& Cartwright, S. (1994) Healthy mind; healthy organization - a proactive approach to occupational stress, Human Relations, Vol. 47, pp. 455-471.

Cooper, C. L., Dewe, P. J. and O'Driscoll, M. P. (2001) Organisational stress: a review and critique of theory, research and applications. Sage Publications: CA.

Edworthy, A. (2000) Managing stress. Open University Press: Buckingham.

Faruquie D.S., Khan M.N. \& Imran T. (2005) Job stress and job anxiety amongst call centre executives in Hussain, A \& Khan, M.I. (Eds.) Recent trends in human stress management. New Delhi: Global Vision.

Fernie, S \& Metcalf, D (1998) (not) hanging on the telephone: Payment systems in the new sweatshops, CEP Discussion Paper, No. 390, pp. 1-41

Gentleman, A. (2005) Indian call staff quit over abuse on the line. Available at: http://www.guardian.co.uk/world/2005/may/29 /india.ameliagentleman. Accessed on 24.06.2013

Hafner, H. (1968) Psychological disturbances following prolonged persecution. Social Psychiatry, Vol. 3. No. 3, pp. 80-88.

Hersen, M. (1972) Nightmare behavior: a review. Psychological Bulletin, Vol. 78. No. 1, pp. 37-78.

Knights, D \& McCabe, D (1998) What happens when the phone goes wild? Staff, stress and spaces for escape in a BPR telephone banking work regime, Journal of Management Studies, Vol. 35, No. 2

Kumar, A (2013) Delhi call-centre worker abducted and gang-raped at gunpoint as she waited for a taxi home, Daily Mail, March 7. Available at: http://www.dailymail.co.uk/indiahome/indianews/article-2289826/Convergys- BPO-gang-rape-Delhi-centre-workerabducted-raped-gunpoint-waited-taxi-home.html. Accessed on 26.06.2013.

MacDonald, W (2003) The impact of job demands and workload on stress and fatigue, Australian Psychologist, 38 (1), pp. 102-117

McPhate, M. (2005) Outsourcing outrage: Indian call center workers suffer abuse. San Francisco Chronicle (November 17). Available at: http://www.sfgate.com/business/article/Outsourcing-outrage-Indian-call-center-workers-2594713.php. Accessed on 27.06.2103

Mulholland, K (2000) Gender, emotional labour and teamworking in a call centre, Personnel Review, Vol. 31, Issue 3

News24 (2008) Eight friends allegedly gang-raped call centre employee in Faridabad. Available at|: http://www.news24online.com/eightfriends-allegedly-gang-raped-call-centre-employee-in-faridabad_LatestNews24_346.aspx\#. Accessed on 26.06.2013.

Outsour2india (2011) available at: http://www.outsour2india.com/why_india/articles/outsourcing_history.asp. Accessed on 25 December 2011.

Pal, M. \& Buzzanell, P. M. (2008) The Indian call center experience: A case study in changing discourses of identity, identification, and career in a global context. Journal of Business Communication, Vol. 45, No. 1, pp. 31-60

Patel, R (2010) Working the night shift: women in Indian call center industry. Stanford: Stanford University Press

Peaucelle, J,L (2000) From taylorism to post taylorism - simultaneously pursuing several management objectives, Journal of Organisational Change, Vol. 13, No. 5

Poster, W. R. (2007) Saying 'Good Morning' in the night: The reversal of work time in global ICT service work, In Beth A. Rubin (ed.) Workplace temporalities (Research in the Sociology of Work), pp. 55-112, Volume 17, Emerald Group Publishing Limited

Pradhan, J.P. and Abraham, V. (2005) Social and Cultural impact of outsourcing: Emerging issues from Indian Call Canters, Harvard Asia Quarterly, 9 (3). Available at: http://www.asiaquaterly.com. Accessed on 26.06.2013.

Selye, H. (1936) Thymus and adrenals in the response of the organism to injuries and intoxifications, British Journal of Experimental Psychology, Vol. 17, pp. 234-248. 
Selye, H. (1956) The stress of life. McGraw Hill: New York, NY.

Slater, J. (2004) Call of the West: For India's youth, new money fuels a revolution, Wall Stress Journal, - Easter Edition, 27 January. Available at http://online.wsj.com/article/0,,SB107516012545012202,00.html. Accessed on 26.06.2013

Strange, R. E. and Brown D. (1970) Home from the war: a study of psychiatric problems in Vietnam returnees. American Journal of Psychiatry, Vol. 127, No. 4, pp. 488-492.

Sudhashree, V. P., Rohith, K. \& Shrinivas, K. (2005) Issues and concerns of health among call center employees. Indian Journal of Occupational and Environmental Medicine, 9, pp. 129-132

Taylor P. and Bain P. (1999) An assembly line in the head: work and employee relations in the call centre, Industrial Relations Journal, Vol. 30, No. 2, pp. 101-117.

Vaidyanathan, R. (2011) India's call centre growth stall. Available at http://www.bbc.co.uk/magazine-15060641. Accessed on 24.06 .2013

Wolfe, S. G. (1986) Common and grave disorders identified with occupational stress, In Wolfe, S. G. and Finestone, A. J. (Eds.) Occupational stress: health and performance at work (pp. 47-53), PSG Publishing: Littleton. 